\title{
Thermal Evaluation of Applying Combined Cycle Mode to Beijee Gas Turbine Generators
}

\author{
A. Youns Fathi \\ Mechanical Engineering Department \\ University of Mosul, College of Engineering,
}

\begin{abstract}
:
Exhaust gases of gas turbine generators contain a significant amount of thermal energy which can be recovered externally or internally to the cycle itself. The most effective technology option for external heat recovery is the combined gas-steam power plant. The internal recovery conventional solutions are based on thermodynamic regeneration and steam injection.

In this study a thermal analysis and performance evaluation has been carried out to investigate the benefit of applying combined cycle power plant on Beijee simple gas turbine generators. Beijee gas turbine generator has been modeled and simulated to observe its performance including power output, thermal efficiency, specific fuel consumption and exhaust gas temperature as it is operating for the time being. Thereafter, simulation was carried out to investigate the performance of the suggested unit when a combined cycle power plant is used.

Results show that a significant improvement in the performance of Beigee gas turbine unit when a combined cycle mode is applied. For example the power output is found to be increased nearly by $\mathbf{4 9 . 3 \%}$, the thermal efficiency increased nearly by $20 \%$ and the specific fuel consumption decreased nearly by $10 \%$.

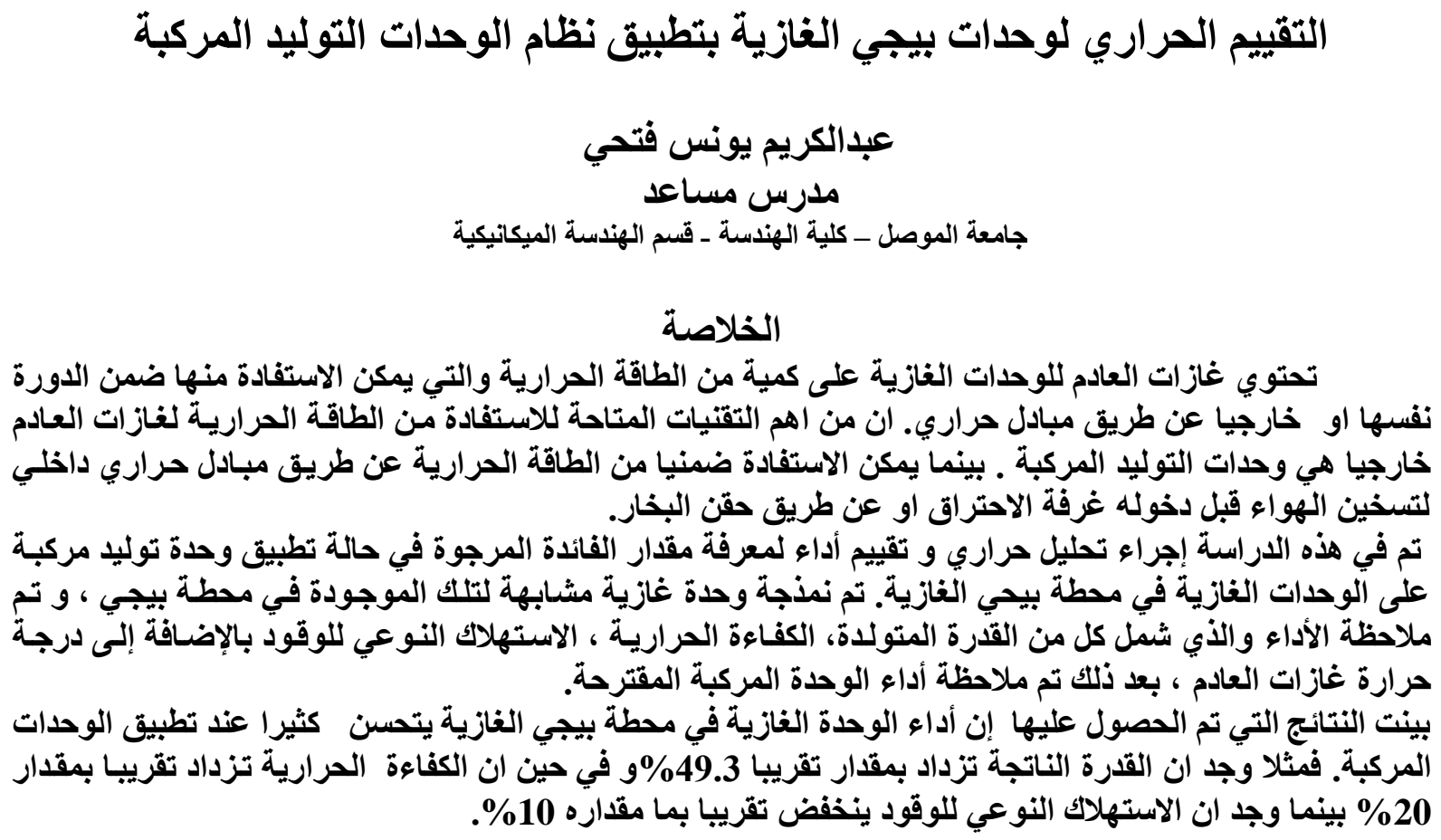

Received: 24 - 4 - 2011

Accepted: $30-6-2011$ 


\section{Introduction}

The use of gas turbines for power generation has been increased recently and likely to continue to do so in the near future. This is due to low capital cost to power ratio, the high flexibility and reliability achievable with simple cycle configuration as well as the high efficiency of integrated solutions of waste heat recovery [1-6]. Thermal energy available in the exhaust of gas turbine generator is usually recovered by means of steam bottoming cycle. However, over the past ten years, the combined gas-steam cycle has become the leading technology for electricity generation, and now days are widely adopted in power plant installation[6-12].

Beijee gas turbine power plant station comprises of four gas turbine generators of 150 MW power output at ISO condition operating on simple cycle mode with compressor pressure ratio of 11 and turbine inlet temperature of $1060{ }^{\circ} \mathrm{C}$. Thus all thermal energy available in the exhaust gases is expelled to atmosphere with out being used for further thermal process. Hence in the current study an investigation is performed to assess the benefit of having a heat recovery steam generator for producing a superheated steam, by extracting thermal energy from gas turbine exhaust, to be directed via a steam turbine for further power production.

\section{Combined Cycle Power plant}

A typical combined cycle power plant is shown in figure (1). The topping cycle is an open Brayton cycle consisting of a compressor, combustion chamber and a gas turbine. A generator converts output shaft power to electric power. Exhaust gases from the topping cycle provides thermal energy to superheat steam in the steam cycle -based bottoming cycle. A heat recovery steam generator (HRSG) that includes an economizer, evaporator and superheater convert compressed liquid water exiting the pump into superheated steam.

Heat recovery steam generator play a very important role in combined cycle power plant $[8,10]$, steam is generated at appropriate temperature and pressure to be provided to steam turbine for further electric power production.

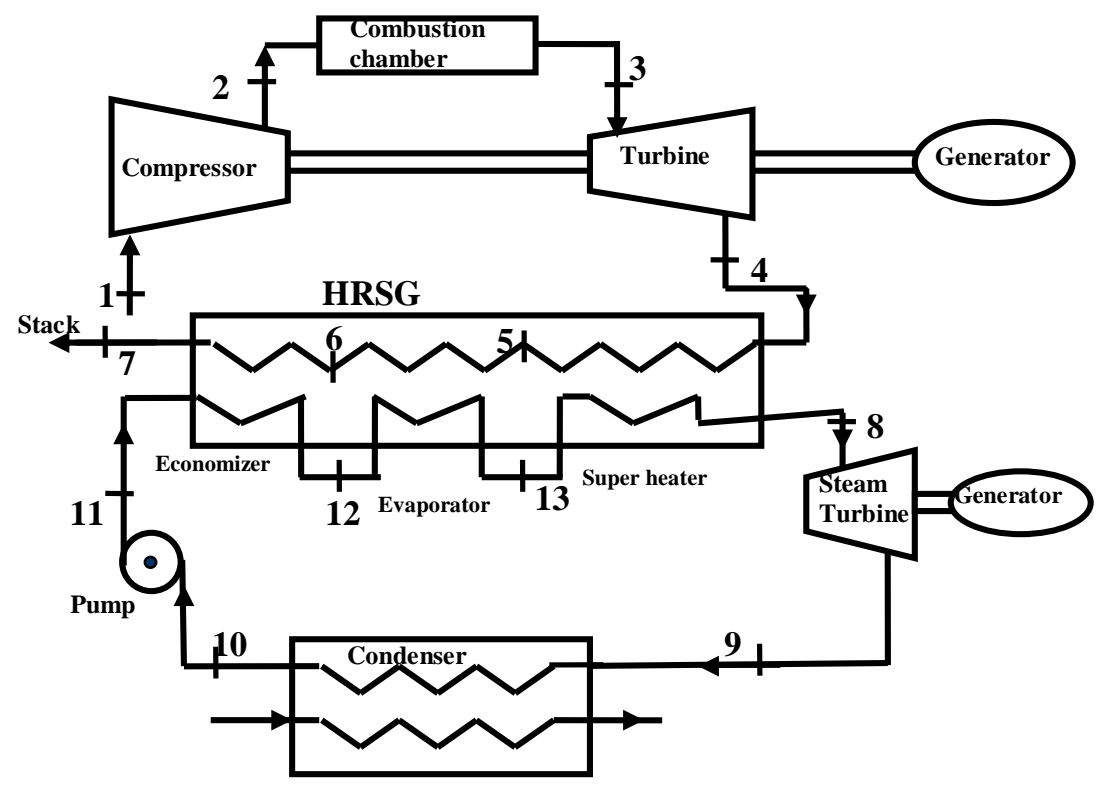

Figure (1): Combined Gas-Steam Power Plant 
The combined gas-steam power plant produces power from the gas turbine and the steam turbine, while only power is required to drive the compressor and the pump.

\section{Thermodynamic Model}

The thermal system to be simulated comprise of a single shaft gas turbine for electricity production similar to those installed at Beijee gas turbine power station as shown in figure (2), a single pressure heat recovery steam generator and a steam turbine for further power production.

\section{Gas Turbine Model}

Gas turbines are steady flow heat engines consisting of three main components, an axial flow compressor, a combustion chamber and an axial flow turbine. A schematic diagram for a simple gas turbine like those is used in Beigee power station is shown in figure (2).

Air is drawn into the gas turbine by the compressor, which compresses and delivers it to the combustion chamber. Within the combustion chamber the air is mixed with fuel and the mixture is ignited, producing a rise in temperature of exhaust gases. These exhaust gases entere the turbine, expand which produce work and finally discharge to atmosphere [1,2]. The reference thermodynamic cycle is an open Brayton- Joule cycle without regeneration.

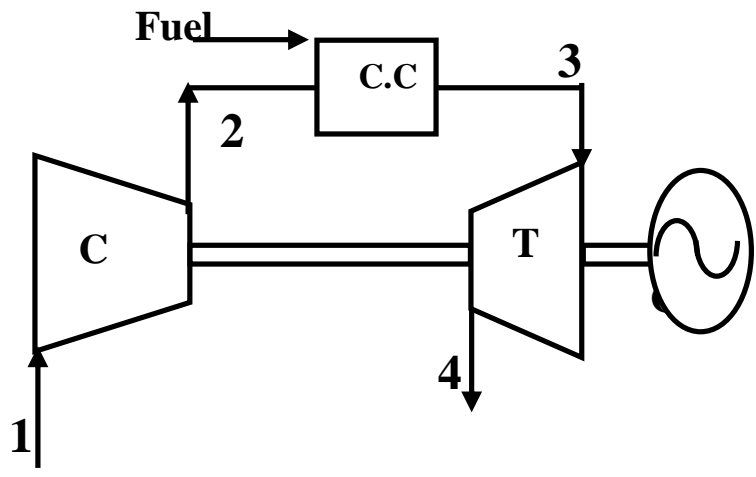

Air

Figure (2): Simple single shaft gas turbine

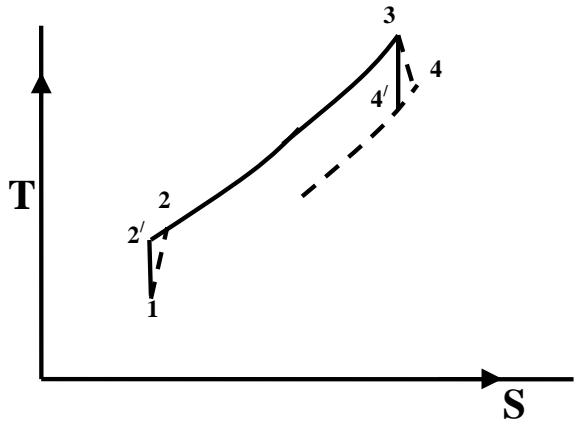

Figure (3) : T-S diagram for simple gas turbine

The following assumptions are considered in the present study:

1. the gas turbine operate on steady state

2. the specific heats of air and hot gases are temperature dependent

3. the fuel is natural gas

4. there is no pressure loss in the inlet and exhaust ducting

5. the amount of heat loss from the combustion chamber is small and can be ignored

Figure (3) show the T-S diagram for the single gas turbine cycle, the ideal and actual processes are represented in dashed and full line respectively. In the axial compressor, air is drawn from atmosphere and compressed from point 1 to point 2 . The mass flow rate is calculated as follows 
$\mathrm{m}=\rho \mathrm{C}_{\mathrm{a}} \mathrm{A}$

where

$\rho$ : density of air at inlet of compressor $\left(\mathrm{kg} / \mathrm{m}^{3}\right)$

$\mathrm{C}_{\mathrm{a}}$ : axial velocity $(\mathrm{m} / \mathrm{s})$

A: the annulus area $\left(\mathrm{m}^{2}\right)$

The density of air is calculated as follows

$\rho=\frac{\mathrm{P}_{1}}{\mathrm{RT}_{1}}$

The ideal compressor exit temperature may be obtained using the following formula

$\mathrm{T}_{2^{\prime}}=\mathrm{T}_{1}\left(\mathrm{r}_{\mathrm{p}}\right)^{\frac{\gamma_{\mathrm{a}}-1}{\gamma_{\mathrm{a}}}}$

And by introducing the compressor isentropic efficiency, the actual compressor exit temperature can be obtained as

$\mathrm{T}_{2}=\left[\frac{\left(\mathrm{T}_{2^{\prime}}-\mathrm{T}_{1}\right)}{\eta_{\mathrm{c}}}+\mathrm{T}_{1}\right]$

Hence, the compressor work can be determined as follows

$\mathrm{W}_{\mathrm{c}}=\mathrm{m} \mathrm{c}_{\mathrm{P}_{\mathrm{a}}}\left(\mathrm{T}_{2}-\mathrm{T}_{1}\right) \quad(\mathrm{kW})$

In the combustion chamber, the heat supplied is due to combustion of hydrocarbon fuel (Natural gas), which is considered as $\mathrm{CH}_{4}$ of lower calorific value of $50000 \mathrm{~kJ} / \mathrm{kg}$ in present study, therefore, the amount of heat added can be obtained as follows

$\mathrm{Q}_{\mathrm{add}}=\mathrm{m}_{\mathrm{f}} * \mathrm{LCV}$

Also

$\mathrm{Q}_{\mathrm{add}}=\mathrm{m}_{\mathrm{a}} \mathrm{c}_{\mathrm{P}_{\mathrm{g}}}\left(\mathrm{T}_{3}-\mathrm{T}_{2}\right)$

However, the turbine inlet temperature (TIT) is limited to $1060{ }^{\circ} \mathrm{C}$ due to metallurgical limit. Hence, the mass flow rate of fuel is calculated according to this temperature. Hot gases leave the combustion chamber and enter the axial flow turbine, expand to atmospheric pressure. Hence, the isentropic turbine exit temperature is given as

$$
\mathrm{T}_{4^{\prime}}=\mathrm{T}_{3} * \frac{1}{\left(\mathrm{r}_{\mathrm{p}}\right)^{\frac{\gamma_{\mathrm{g}}-1}{\gamma_{\mathrm{g}}}}}
$$

And the actual turbine exit temperature is obtained as

$$
\mathrm{T}_{4}=\mathrm{T}_{3}-\eta_{\mathrm{tb}}\left(\mathrm{T}_{3}-\mathrm{T}_{4^{\prime}}\right)
$$

The turbine work is calculated as follows

$$
\mathrm{W}_{\mathrm{t}}=\mathrm{m}_{\mathrm{a}} \mathrm{c}_{\mathrm{P}_{\mathrm{exh}}}\left(\mathrm{T}_{3}-\mathrm{T}_{4}\right) \quad(\mathrm{kW})
$$

The power output is obtained as follows

$$
\mathrm{P}_{\mathrm{GT}}=\mathrm{W}_{\mathrm{t}}-\mathrm{W}_{\mathrm{c}}
$$

The thermal efficiency is found using the following equation

$\eta_{\mathrm{GT}}=\frac{\mathrm{P}_{\mathrm{Gt}}}{\mathrm{Q}_{\mathrm{add}}}=\frac{\mathrm{P}_{\mathrm{GT}}}{\mathrm{m}_{\mathrm{f}} * \mathrm{LCV}}$

And finally the specific fuel consumption is obtained as follows 
$\mathrm{SFC}_{\mathrm{GT}}=\frac{\mathrm{m}_{\mathrm{f}}}{\mathrm{P}_{\mathrm{GT}}} * 3600 \quad(\mathrm{~kg} / \mathrm{kW} . \mathrm{h})$

\section{Heat Recovery Steam Generator Model}

The performance of the heat recovery steam generator (HRSG) strongly affects the overall performance of combined cycle power plant. HRSG performance is usually based on the concept of pinch point and approach point that govern the gas and steam temperature profile. The pinch point represent the difference between the gas temperature leaving the evaporator and saturation temperature, while the approach point temperature is the difference between the water temperature leaving the economizer and saturation temperature as shown in figure(4).

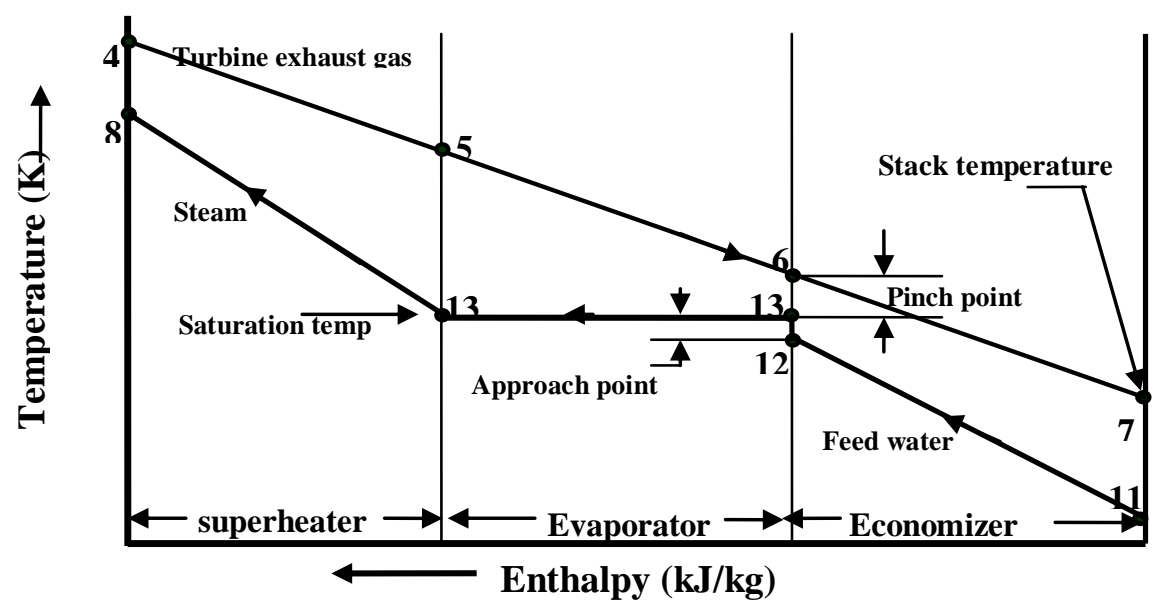

Figure (4): Temperature profile in a single pressure HRSG

In present study a single pressure heat recovery steam generator is considered which consist of economizer, evaporator and super heater as shown in figure (1). The waste heat from gas turbine is recovered in generating steam at required pressure and temperature.

The amount of heat available in gas exhaust can be obtained as follows:

$\mathrm{Q}_{\mathrm{exh}}=\mathrm{m}_{\mathrm{exh}} \mathrm{c}_{\mathrm{P}_{\text {exh }}}\left(\mathrm{T}_{4}-\mathrm{T}_{5}\right) \quad(\mathrm{kW})$

The amount of heat transferred to the feed water in the economizer can be worked out as follows

$\mathrm{Q}_{\mathrm{ec}}=\mathrm{m}_{\mathrm{w}} \varepsilon_{\mathrm{ec}}\left(\mathrm{h}_{12}-\mathrm{h}_{11}\right) \quad(\mathrm{kW})$

The amount of heat transferred in the evaporator to get saturated steam may be estimated as follows

$\mathrm{Q}_{\mathrm{ev}}=\mathrm{m}_{\mathrm{s}} \varepsilon_{\mathrm{ev}}\left(\mathrm{h}_{13}-\mathrm{h}_{12}\right) \quad(\mathrm{kW})$

Finally, the saturated steam leaving the evaporator enter the super heater to be heated to superheated temperature, hence the amount of heat absorbed by the steam in the super heater is given as

$\mathrm{Q}_{\text {sup }}=\mathrm{m}_{\mathrm{s}} \varepsilon_{\text {sup }}\left(\mathrm{h}_{8}-\mathrm{h}_{13}\right) \quad(\mathrm{kW})$

Therefore, the total heat gained by the heat recovery steam generator from the gas turbine exhaust is calculated as

$\mathrm{Q}_{\mathrm{HRSG}}=\mathrm{Q}_{\mathrm{ec}}+\mathrm{Q}_{\mathrm{ev}}+\mathrm{Q}_{\text {sup }} \quad(\mathrm{kW})$

\section{Steam Turbine Model}


Steam generated in the heat recovery steam generator is directed to be expands in steam turbine to condenser pressure for further power production. The steam turbine power out put can be calculated as follows

$$
\mathrm{P}_{\mathrm{st}}=\mathrm{m}_{\mathrm{s}}\left(\mathrm{h}_{8}-\mathrm{h}_{9}\right) \quad(\mathrm{kW})
$$

Hence, the total power out put of the combined cycle is given as

$$
\mathrm{P}_{\text {वCGT }}=\mathrm{P}_{\mathrm{GT}}+\mathrm{P}_{\mathrm{st}} \quad(\mathrm{kW})
$$

The combined cycle efficiency can be obtained a follows

$$
\eta_{\mathrm{ccGT}}=\frac{\mathrm{P}_{\mathrm{GT}}+\mathrm{P}_{\mathrm{st}}}{\mathrm{m}_{\mathrm{f}} * \mathrm{LCV}}
$$

The specific fuel consumption is obtained as follows

$$
\mathrm{SFC}_{\mathrm{ccGT}}=\frac{\mathrm{m}_{\mathrm{f}}}{\mathrm{P}_{\mathrm{cCGT}}} * 3600 \quad(\mathrm{~kg} / \mathrm{kW} \cdot \mathrm{h})
$$

\section{Result and Discussion}

The thermodynamic analysis of present Beigee simple gas turbine and the suggested combined cycle power plant with single pressure heat recovery steam generator has been carried out for the following input parameters :- TIT $=1060^{\circ} \mathrm{C}, \mathrm{m}=509 \mathrm{~kg} / \mathrm{s}, \mathrm{rp}=11, \eta_{\mathrm{c}}=0.88$ and $\eta_{\mathrm{tb}}=0.9$.

First, the performance of Beigee simple gas turbine generator is performed to investigate the effect of ambient temperature on its performance. Figure (5) shows the relationship between the mass flow rate of air discharged by the compressor and the ambient temperature. It was found that there is nearly $11.6 \%$ reduction in the mass of air from the design value as the temperature reaches $45{ }^{\circ} \mathrm{C}$. This is due to the decrease in density of the ambient air with the increase of its temperature, which affects the mass flow rate of air delivered by the compressor.

As expected, the power output found to decrease as ambient temperature increase, as shown in figure (6). This is due to the reduction in the mass flow rate of air with ambient temperature rise, which affect the pressure ratio and the turbine work and ultimately the power output. The reduction in power output found to be $25.3 \%$ as the ambient temperature reaches 45
${ }^{\circ} \mathrm{C}$. Figure
(7) shows
the

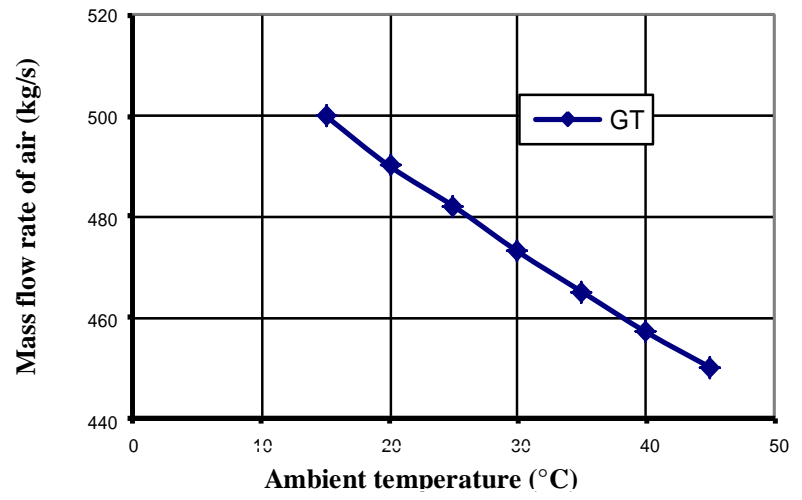

Figure (5): Effect of ambient temperature on the mass flow rate of air



Figure (6): Effect of ambient temperature on power 
relationship between the thermal efficiency and ambient temperature. It can seen that the thermal efficiency decrease with ambient temperature. This may be due to the decrease in the power output and the slight increase in specific fuel consumption. In this case, the thermal efficiency was found to decrease by nearly $8 \%$ as the ambient temperature approaches 45 ${ }^{\circ} \mathrm{C}$.

In figure (8), the specific fuel consumption is plotted against the ambient temperature. It was found that the specific fuel consumption increases by approximately $7.4 \%$. The relatively high increase is due to the reduction in the pressure ratio and compressor work, which made it necessary to increase the mass flow rate of fuel to keep the turbine inlet temperature constant at $1060{ }^{\circ} \mathrm{C}$. Figure (9) shows the relationship between the ambient temperature and exhaust gas temperature. It can be seen that exhaust gas temperature increase nearly by $30{ }^{\circ} \mathrm{C}$ as the ambient temperature approaches $45^{\circ} \mathrm{C}$.

Thereafter, the effect of pinch point and approach point temperature was investigated. Figure (10) shows the relationship between the pinch point and the mass flow rate of steam generated by the heat recovery steam generator. It can be seen that the mass of generated steam decreases nearly by $21.5 \%$ as the pinch point increase from $5{ }^{\circ} \mathrm{C}$ to $40{ }^{\circ} \mathrm{C}$.

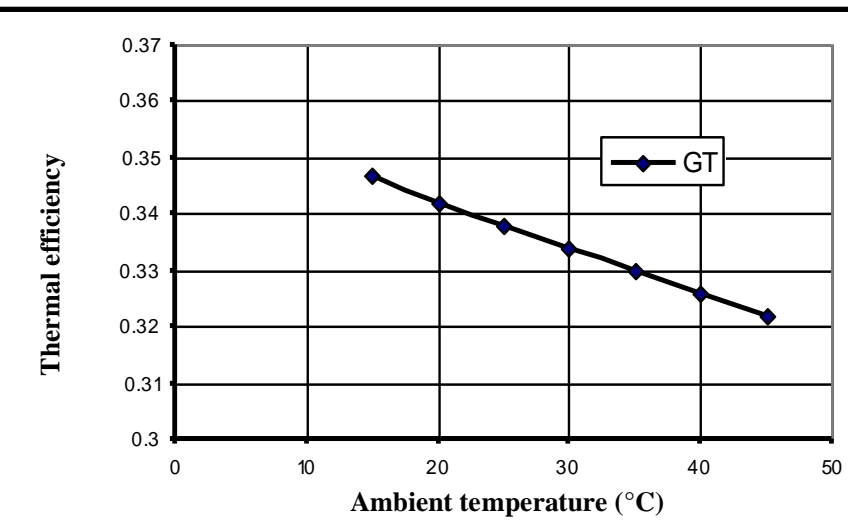

Figure (7): Effect of ambient temperature on thermal efficiency

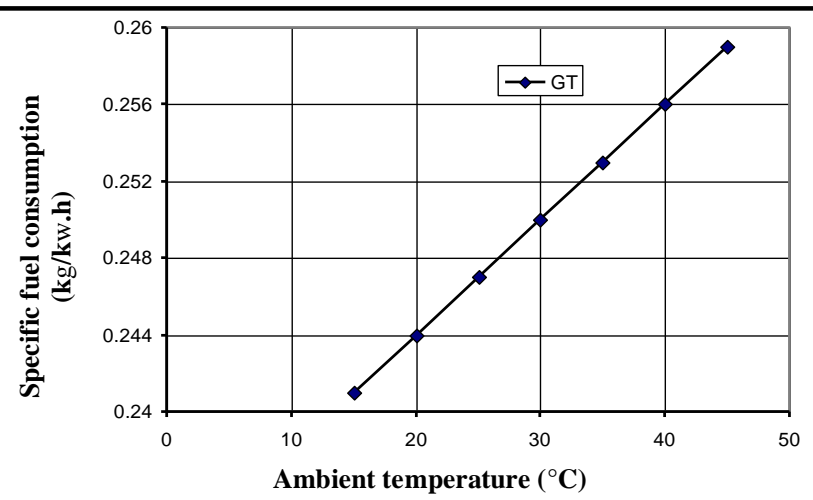

Figure (8): Effect of ambient temperature on specific fuel consumption

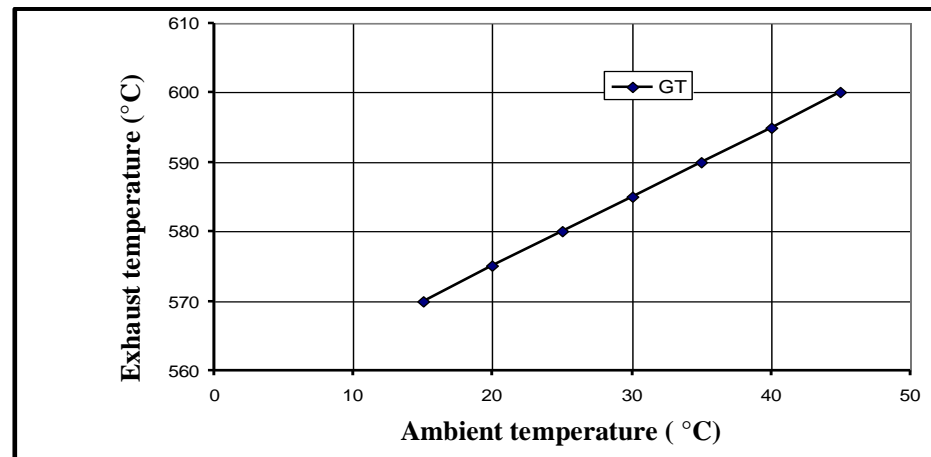

Figure (9): Effect of ambient temperature on gas turbine exhaust temperature

Because of that, the steam turbine power output decrease nearly by $18.9 \%$ as pictured in figure (11). This is due to reduction in the heat transfer that take place in the heat recovery steam generator which effect its thermal efficiency a given in figure (12). Similar results found for the approach point temperature affect, as shown in figures (13), (14) and (15). It was found that the steam generated by the HRSG, steam turbine output and the heat recovery steam generator thermal efficiency decreases nearly by $14 \%, 19 \%$ and $15.6 \%$ respectively as the approach point increase from $5{ }^{\circ} \mathrm{C}$ to $40{ }^{\circ} \mathrm{C}$. 
Finally, the thermal benefit of applying combined cycle mode on Beigee simple gas turbine generator is pictured in figure (16), (17) and (18). Examining Figure (16), it can be seen that the power output produced by the combined cycle is higher than that produced by simple gas turbine unit nearly by $49.3 \%$. This is due to the extra power produced by the bottoming cycle (steam cycle) which takes its thermal energy from the exhaust



Figure (10): Effect of pinch point on the mass flow rate of steam generated by the HRSG. gases. Figure (17) give a comparison of thermal efficiency of simple gas unit and combined cycle as function of ambient temperature. This figure indicates that the thermal efficiency can be increased nearly by $20 \%$ when combined cycle mode is used. On other hand the specific fuel consumption was found to be decreased nearly by $10 \%$ as shown in figure (18).

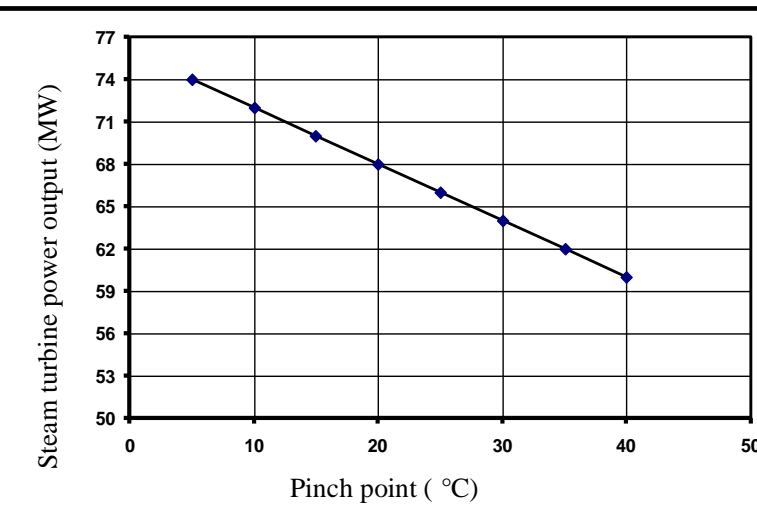

Figure (11): Effect of pinch point on the steam turbine power output



Figure (13): Effect of approach point on the mass flow rate of generated steam

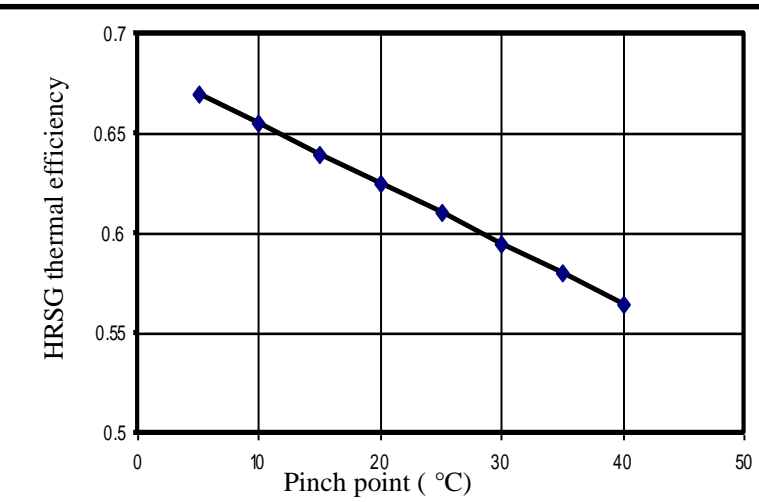

Figure (12): Effect of pinch point on HRSG

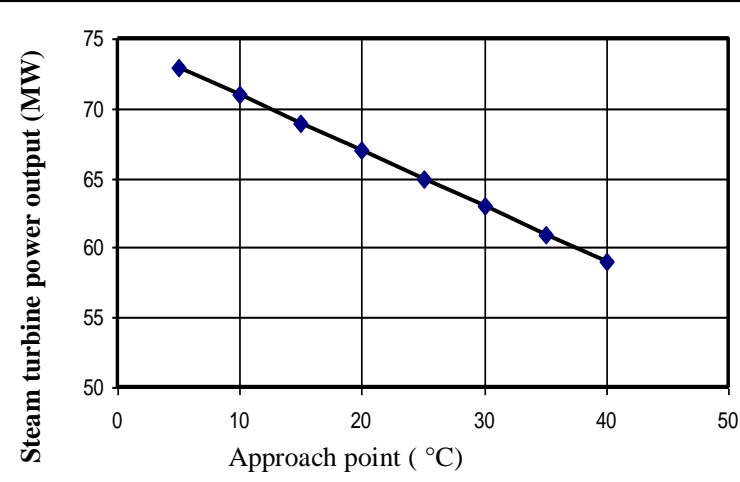

Figure (14): Effect of Approach point on the steam turbine power output 
Fathi: Thermal Evaluation of Applying Combined Cycle Mode to Beijee Gas Turbine

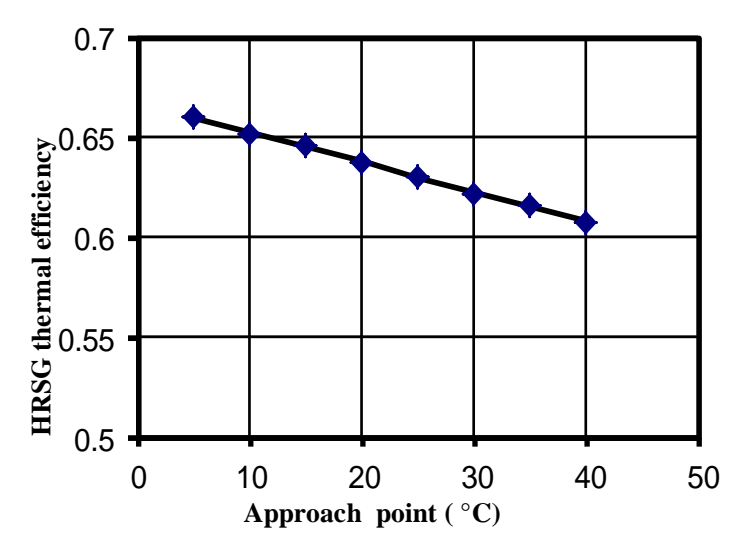

Figure (15): Effect of approach point on HRSG thermal efficiency

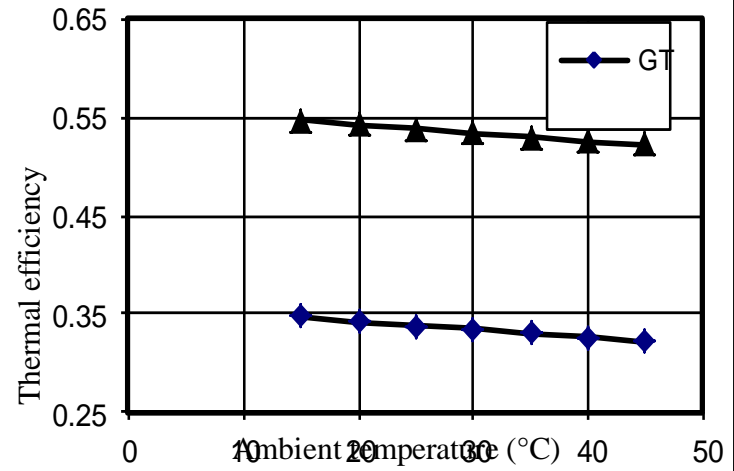

Figure (17): Comparison of simple gas turbine and combined cycle power plant thermal efficiency at various ambient temperatures

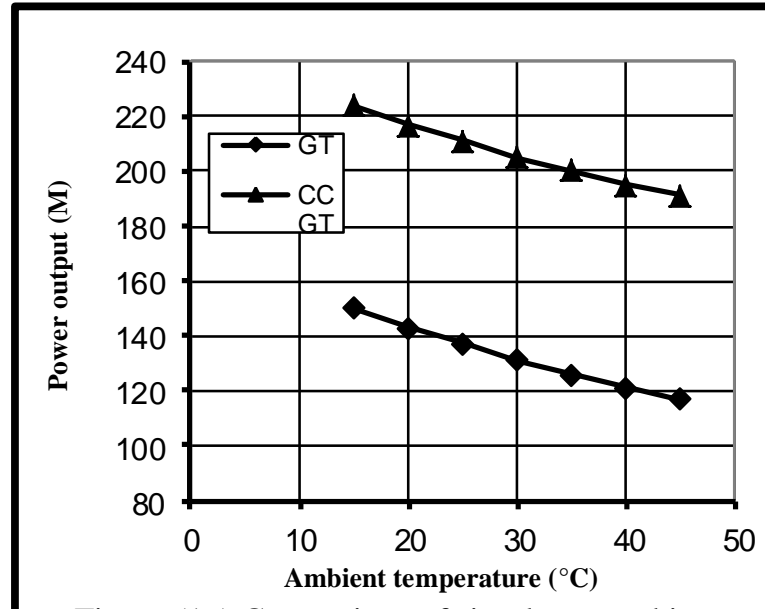

Figure (16) Comparison of simple gas turbine and combined cycle power plant output at various ambient temperatures

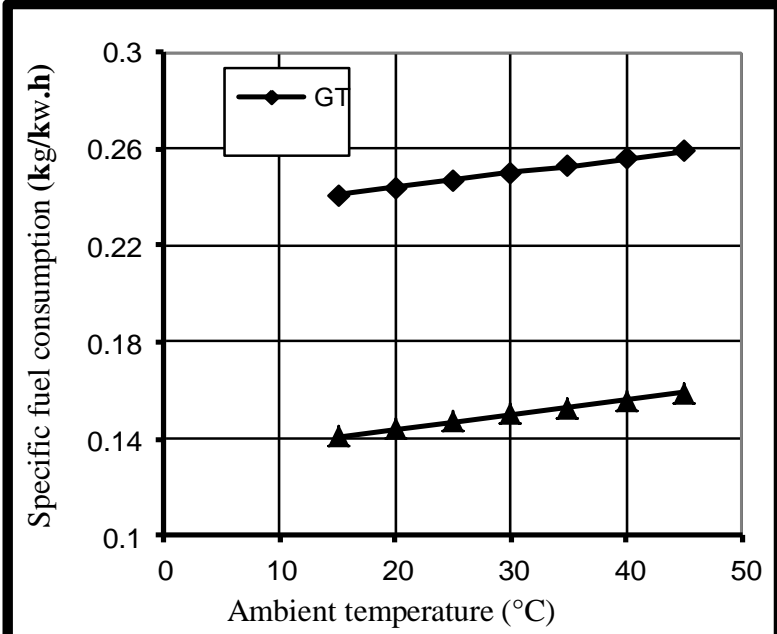

Figure (18): Comparison of simple gas turbine and combined cycle power plant specific fuel consumption at various ambient temperatures

\section{Nomenclature}

$\begin{array}{ll}\mathrm{A} & \text { Annulus area }\left(\mathrm{m}^{2}\right) \\ \mathrm{Ca} & \text { Axial velocity }(\mathrm{m} / \mathrm{s}) \\ \mathrm{Cp} & \text { Specific heat at constant pressure }(\mathrm{kJ} / \mathrm{kg} \cdot \mathrm{K}) \\ \mathrm{h} & \text { Enthalpy }(\mathrm{kJ} / \mathrm{kg}) \\ \mathrm{LCV} & \text { Lower calorific value }(\mathrm{kJ} / \mathrm{kg}) \\ \mathrm{m} & \text { Mass flow rate }(\mathrm{kg} / \mathrm{s}) \\ \mathrm{P} & \text { Pressure }(\mathrm{bar}) \\ \mathrm{P} & \text { Power }(\mathrm{KW}) \\ \mathrm{Q} & \text { Heat }(\mathrm{KW}) \\ & \\ \mathrm{rp} & \text { Pressure ratio } \\ \mathrm{SFC} & \text { Specific fuel consumption }(\mathrm{kg} / \mathrm{kw} \cdot \mathrm{h}) \\ \mathrm{W} & \text { Work }(\mathrm{KW}) \\ \mathrm{T} & \text { Temperature }(\mathrm{K})\end{array}$

\section{Subscripts}

$\begin{array}{ll}\text { a } & \text { Air } \\ \text { c } & \text { Compressor } \\ \text { CCGT } & \text { Combined cycle } \\ \text { ec } & \text { Economizer } \\ \text { ev } & \text { Evaporator } \\ \text { exh } & \text { Exhaust gases } \\ \text { f } & \text { Fuel } \\ \text { GT } & \text { simple gas turbine } \\ \text { HRSG } & \text { Heat recovery steam } \\ & \text { generator } \\ \text { s } & \text { Steam } \\ \text { st } & \text { Steam turbine } \\ \text { sup } & \text { Superheater } \\ \text { tb } & \text { Turbine }\end{array}$




\section{References}

1- Malewski W. F., and Holldorft, G. M., Power Increase of Gas turbine by Inlet Air Precooling with Absorption Refrigeration Utilizing Exhaust Waste Heat, ASME International Gas Turbine Conference, Paper No 86-GT-67, Duseldorf June 1986

2- De Lucia M., Bronconi, R., and Carneval, E., Performance and Economic Enhancement of Cogeneration Gas Turbine Through Compressor Inlet Air Cooling, ASME Journal of Engineering for Gas Turbine and Power, Vol. 116, pp.360-365, 1994.

3- A. Ongiro, V.I.Ugursal, A.M.Al-Taweel and J.D. walker, Modeling of Heat Recovery Seam Generator Performance , Applied Thermal Engineering Vol.17, No.5, pp427-446, 1997

4- A.Agazzani, A.F.Maardo, A Tool for Thermo-economic Analysis and Optimization of Gas, Steam and Combine Plants, Journal of Engineering for Gas Turbine and Power ,Vol119, pp885-892, Oct. 1997

5- Jan Szargut, Influence of the Ambient Temperature on the Operational Indices of the Gas Turbine Set, International Journal of Energy Research, Vol. 24, pp. 821-830, 1999.

6- Alaandro Franco, Claudio Casarosa, On Some Perspective for Increasing the Efficiency of Combined Cycle Power Plants, Applied Thermal Engineering,Vol.22, pp1501-1518, 2002.

7- X. Q. Kang, R.Z . Wang, X.H.Huang, Energy Optimization Mode for A CCHP System with Available Gas Turbines, Applied Thermal Engineering,Vol.5, pp377-391, 2005.

8- Naradasu Ravi Kumer, Knoijeti Rama Krishna and Alluru Venkata Sita Rama, Thermodynamic Analysis of Heat Recovery Steam Generator in Combined Cycle Power Plants, Thermal Science Vol.11, No.4, pp 143-156,2007

9- A. Khaliq, K.Choudhary, Combined First and Second Law Analysis of Gas Turbine Cogeneration System with Inlet Cooling and Evaporative After cooling of the Compressor Discharge , Journal of Engineering for Gas Turbine and Power, Vol. 19 , pp1004-1011, Oct. 2007

10- Roberto Carapellucci, A Unified Approach to Assess Performance of Different Techniques for Recovering Exhaust Heat From Gas Turbines, Energy Conversion and Management Vol.50, pp1218-1226, 2009.

11- Ali Behbahani et al, Optimization of Fire Tube Heat Recovery Steam Generators for Cogeneration Plant Through Genetic Algorithm, Applied Thermal Engineering,Vol.30, pp2378-2385, 2010.

12- Ashok Kumar, S S Kahwaha and R S Mishra, Thermodynamic Analysis of a Regenrative Gas Turbine Cogeneration Plants, Journal of Scientific and Industrial Research, Vol.61, pp 225-231, March 2010 